\title{
Neural network for crop rotation and soil analysis in a Greenhouse
}

\section{Red Neuronal para la rotación de cultivos y análisis de suelo en un Invernadero}

\author{
RAFAEL-PÉREZ, Eva†*, MONTERO-CORTÉS, Yeimi Yanet, RUIZ-RAMÍREZ, Alan Eduardo and \\ MORALES-HERNÁNDEZ, Maricela
}

Tecnológico Nacional de Méxicol Instituto Tecnológico de Oaxaca, Departamento de Sistemas y Computación. Avenida Ing. Víctor Bravo Ahuja No. 125 Esquina Calzada Tecnológico, Oaxaca, Oax., México. C.P. 68030

ID $1^{\text {st }}$ Author: Eva, Rafael-Pérez / ORC ID: 0000-0003-2793-1254, CVU CONACYT ID: 905268

ID $1^{\text {st }}$ Co-author: Yeimi Yanet, Montero-Cortés / ORC ID: -0000-0001-5510-7241 CVU CONACYT ID: 1148726

ID $2^{\text {nd }}$ Co-author: Alan Eduardo, Ruiz-Ramírez / ORC ID: -0000-0001-9269-5951 CVU CONACYT ID: 1148734

ID $3^{\text {rd }}$ Co-author: Maricela, Morales-Hernández / ORC ID: 0000-0002-3521-2041, CVU CONACYT ID: 731036

\begin{abstract}
Currently, Artificial intelligence (AI) is a very important area, the way in which it has revolutionized has allowed it to be an essential part of technological evolution in different sectors of society such as agriculture, it is a fundamental activity in the development of our country, and one of the developing areas is implementation of greenhouse crop. This article describes the use of artificial intelligence for a greenhouse through an Artificial Neural Network (ANN) of the multilayer perceptron type using the BackPropagation algorithm. The main aim is obtain the most optimal type of crop to be sown by means of the crop rotation, which, supported by a data acquisition device through sensors, obtains the values of temperature and humidity of the environment and soil $\mathrm{pH}$, with those data the ANN makes the soil analysis. Through the interfaces of the data analysis module and the measurement module, the data collection process, the calculation and the results produced by the artificial neural network are shown. For this project, the Prototype model was used using the Java programming language.
\end{abstract}

Artificial Neural Network, Crop rotation, Soil analysis

\begin{abstract}
Resumen
La inteligencia artificial (IA) es un área importante en la actualidad, la manera en cómo ha revolucionado le ha permitido ser parte esencial de la evolución tecnológica en varios sectores de la sociedad como es la agricultura, actividad fundamental en el desarrollo de nuestro país que se ve implementada en la producción de cultivos bajo invernadero. El presente artículo describe el uso de la inteligencia artificial para un invernadero a través de una Red Neuronal Artificial (RNA) de tipo perceptrón multicapa utilizando el algoritmo de BackPropagation, con el objetivo de obtener el tipo de cultivo más óptimo a sembrar por medio de la rotación de cultivos, que apoyados de un dispositivo de adquisición de datos a través de sensores se obtuvieron los valores de temperatura y humedad del ambiente y $\mathrm{pH}$ del suelo para realizar el análisis del suelo. Mediante las interfaces del módulo de análisis de datos y del módulo de mediciones se muestra el proceso de obtención de datos, el cálculo y los resultados que arroja la red neuronal artificial. Para este proyecto se utilizó el modelo en Prototipos utilizando el lenguaje de programación Java.
\end{abstract}

Red Neuronal Artificial, Rotación de cultivos, Análisis de suelo

Citation: RAFAEL-PÉREZ, Eva, MONTERO-CORTÉS, Yeimi Yanet, RUIZ-RAMÍREZ, Alan Eduardo and MORALESHERNÁNDEZ, Maricela. Neural network for crop rotation and soil analysis in a Greenhouse. ECORFAN JournalDemocratic Republic of Congo. 2021, 7-12: 29.41

\footnotetext{
* Correspondence to Author (e-mail: evarafaelperez@ gmail.com)

$\dagger$ Researcher contributing first author.
} 


\section{Introduction}

The incorporation of artificial intelligence has transformed the form and way of life in human beings, the way of production in agriculture has changed, currently agriculture considers various methods of production, efficient and high performance as protected agriculture, which is defined as a specialized agricultural system in which a certain control of the climatic environment is carried out, altering its conditions: soil, temperature, solar radiation, wind, humidity and atmospheric composition (Castellanos-Ramos, 2004). According to data from the Mexican Association of Protected Horticulture (AMHPAC), there are a total of 25,814 active protected agriculture facilities.

The project called Neural Network for Crop Rotation and Soil Analysis in a Greenhouse was developed with the objective of supporting the farmer in making a decision on the optimal type of crop to plant in the greenhouse. It is called optimal crop to the results that are thrown after having performed the soil analysis, taken measurements of temperature, humidity and $\mathrm{pH}$ of the soil through the data acquisition module, having selected the type of previous family that was planted based on the technique of crop rotation technique and the application and analysis of the neural network, i.e., once the process is done, the results generated are: The most optimal type of crop to be planted, the optimal humidity values and the ranges in which they should be, the optimal temperature for the type of crop to be planted and the ranges in which it should be and the corresponding family.

\section{The production of crops under greenhouse is one of the most modern techniques currently used in agricultural production that is implemented through a greenhouse that provides an appropriate environment, both in the soil and in the air for the cultivation of plant species, which is supported by techniques to improve crop production.}

In this case it was supported by the technique of crop rotation, which is an agricultural practice to increase the productivity of the land and optimize the use of resources by alternating different types of crops in the same soil, its use helps to reduce soil "fatigue" (Seminis, 2016).
Since through the neural network and soil analysis through the values of humidity and temperature of the environment, as well as soil $\mathrm{pH}$, the type of the optimal crop to plant is determined, thus avoiding the risk of loss of production and unnecessary expenses for the farmer. The basic principle of rotations is that crops follow one another according to the characteristics between the preceding crop and the following one, waiting some time to replant a certain crop in the same plot. When designing a rotation, crops with different characteristics should be combined, always taking into account the effect that each crop produces on fertilization and soil structure.

This project was based on the technique of 4 groups of 8 families, starting with the Solanaceae family, then the Leguminosae family, then the Compositae family and finally the Umbelliferae family. For soil analysis, a data acquisition module was used, which consists of taking samples from the real world (analog system) to generate data that can be manipulated by a computer, it is composed of the breadboard, sensors, arduino and electrode.

It is worth mentioning that for the purposes of this work, only the data acquisition module will be explained in general terms, since it is a fundamental part to obtain the values for the measurement, perform the calculations and the results generated by the neural network. The detailed operation and design will be presented for the purposes of another future work.

Likewise, the expert system on which the neural network for crop rotation and soil analysis in its version 2.0 is based, for the purposes of this article will be explained only the functionality of the modules that were added such as: Soil Analysis and Measurements to explain the functionality of the neural network and the values generated by the data acquisition module.

Therefore, this article contains the problem statement, the data acquisition module including the materials and the circuit design; a section on the artificial neural network that covers the part of the operation, the design, the data of the Network and the BackPropagation Algorithm that was used for the neural network programming, another part of the work is the description of the phases for the learning and the presentation of the neural network.

RAFAEL-PÉREZ, Eva, MONTERO-CORTÉS, Yeimi Yanet, RUIZRAMÍREZ, Alan Eduardo and MORALES-HERNÁNDEZ, Maricela. Neural network for crop rotation and soil analysis in a Greenhouse. ECORFAN Journal-Democratic Republic of Congo. 2021 
A section of the crop rotation, the development methodology using the model in prototypes and the description of the stages, then the results of the soil analysis module, the functionality of the neural network and the data acquisition module, the acknowledgements and finally the conclusions and bibliographical references.

\section{Problem Statement}

The production of crops under greenhouse is one of the most modern techniques currently used in agricultural production, one of the main problems of any greenhouse is when the monoculture system is practiced, as it has certain disadvantages, the soil suffers a wear of nutrients because the same plant is planted in the same place which depletes the nutrients it needs, for example the lack of nitrogen in the soil prevents the growth of plants, The tendency towards erosion and drought, also with the production of a single crop there is a greater likelihood of soil impoverishment, since the same nutrients are abused, and greater exposure to pests and diseases, this creates a risk for the farmer because he bases his production on a single crop endangering his entire crop and therefore economic losses occur, or also that the product often has no quality.

\section{Data acquisition module}

For the correct operation of the neural network for soil analysis in the crop rotation in a greenhouse, it is necessary to rely on a data acquisition module; data obtained will be used for the training phase of the neural network, in addition to predicting whether the soil and environmental data are favorable for the harvest of plants of a specific family.

\section{Materials}

For the design of the data acquisition module, the following materials were used

$\begin{array}{lll}- & \text { Dht11 (temperature and humidity } \\ & \text { sensor) } \\ - & \text { Arduino Uno } \\ - & \text { Protoboard } \\ - & \text { Ph-4502C (pH sensor) } \\ - & \text { Electrode }\end{array}$

\section{Circuit diagram}

Figure 1 shows the design of the circuit diagram that was used to obtain data through the dht11 sensor which is used to obtain temperature and humidity from the environment in addition to the $\mathrm{Ph}-4502 \mathrm{C}$ sensor for $\mathrm{pH}$ values.
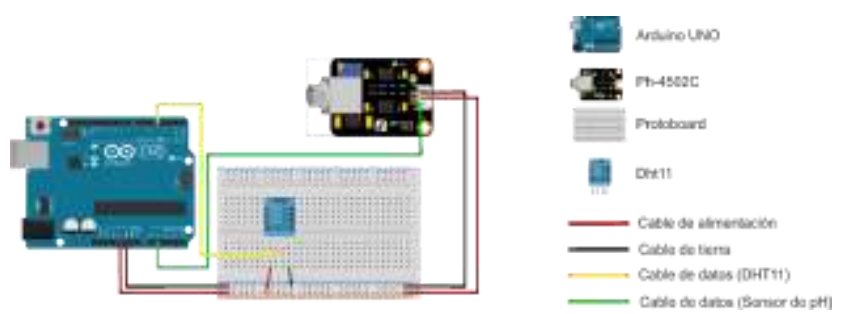

Figure 1 Circuit diagram Source: Own Elaboration

\section{Artificial Neural Network}

Artificial Intelligence is an area with greater growth in recent years, for Iberdrola, (2019) AI is able to analyze data in large quantities, identify patterns and trends and, therefore, formulate predictions automatically, quickly and accurately, one of its areas are artificial neural networks.

Biological neuron, it was Santiago Ramón y Cajal (1888) who discovered the cellular structure (neuron) of the nervous system. He defended the theory that neurons interconnected with each other in parallel, consisting of a cell body (soma) of between 10 and $80 \mathrm{~mm}$, from which a dense tree of branches (dendrites) and a tubular fiber (axon) of between $100 \mathrm{~mm}$ and one meter.

On the other hand, Anderson (1995) defines the artificial neural network as a computational model inspired by biological neural networks, which can be considered as an information processing system with a distributed structure of parallel processing, formed by processing elements that are the artificial neurons, which are interconnected by a large number of connections called synapses.

These connections are used to store information that is available for use. An artificial neuron is intended to mimic the most important characteristics of biological neurons. Figure 2 shows the comparison between the biological neuron and the artificial neuron. 


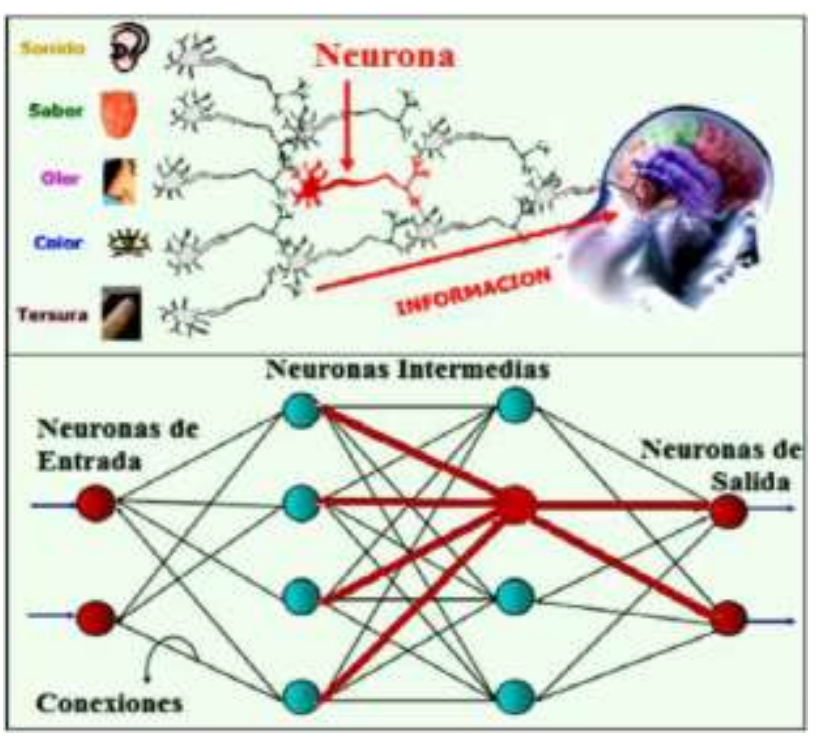

Figure 2 Comparison between biological and artificial neuron

Source: Hilera, J. and Martínez, V. 1995

\section{Functioning of a Neural Network}

A neural network is a set of artificial neurons divided into layers. Each neuron of a layer will be connected with all the neurons of the next layer by means of arcs with weights. The weights of these arcs will be modified during the learning phase of the neural network to achieve the desired results in the output of the network.

The layers of the network will be divided into three types: the input layer, the hidden layer(s) and the output layer. The input layer will be the first layer of the network and the data will be fed into the network through it. In this layer there will be as many neurons as the number of inputs required by the network. The hidden layer can be a single layer or there can be several hidden layers, depending on the problem and the design of the network. This layer will be in charge of carrying out the intermediate step or steps between the input layer and the output layer. (Valencia Reyes, Yañez Márquez, and Sánchez Chávez, 2006).

The output layer will be in charge of taking the results obtained to the outside. The number of neurons in this layer will be defined by the problem being solved.

\section{Neural Network Design}

The type of neural network used is a multilayer perceptron. Figure 3 shows the structure of the neural network on which the neural network design was based.

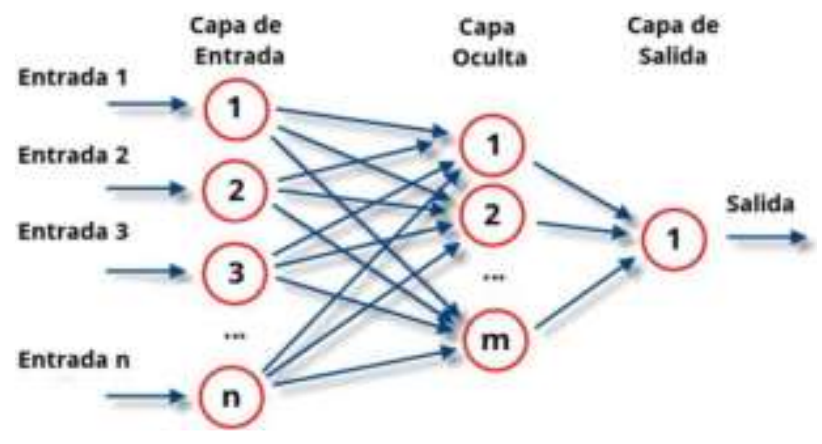

Figure 3 Neural network structure Source: IBM Knowledge Center

\section{Neural Network Data}

The data that were used for the network are:

- $\quad$ An input layer of 5 neurons.

- $\quad$ Two hidden layers of 19 and 20 neurons respectively.

- $\quad$ An output layer with 51 neurons

- $\quad$ BackPropagation Algorithm

In 1986, Rumelhart, Hinton and Williams, formalized an algorithm for a neural network to learn the association that exists between input patterns and corresponding classes, using several levels of neurons.

\section{Steps to apply the backpropagation algorithm}

1. Initialize the weights of the network with random small values.

2. Present an input pattern and specify the desired output to be generated by the network.

3. Calculate the actual output of the network. To do this, the inputs to the network are presented and the output of each layer is calculated until the output layer is reached, this will be the output of the network.

4. Calculate the error terms for all neurons.

5. Update the weights: for this we use a recursive algorithm, starting with the output neurons and working backwards until reaching the input layer, adjusting the weights.

6. The process is repeated until the error term is acceptably small for each of the learned patterns.

The Java programming language was used to develop the neural network. 


\section{Neural network processing phases}

\section{A. Learning Phase}

In this phase a network is initially generic and through a series of examples the weights of the arcs will be adapted in such a way that it produces the desired outputs.

Testing and learning of the neural network. A pattern recognition dataset (Iris) obtained from https://archive.ics.uci.edu/ml/datasets/iris was used for this process.

The dataset contains 50 samples of each of three species of Iris (Iris setosa, Iris virginica and Iris versicolor).

\section{Neural network test values}

$\begin{array}{ll}- & 4 \text { input neurons } \\ - & 8 \text { neurons in the hidden layer } \\ - & 3 \text { neurons in the output layer } \\ - & \text { Learning factor of } 0.05 \\ - & \begin{array}{l}\text { Maximum allowed root mean square } \\ \text { error } 0.005\end{array}\end{array}$

Figure 4 shows the result of the error percentage of the iris data set, once the neural network is trained, the data in the graph shows that the $\mathrm{y}$ variable does not vary as the $\mathrm{x}$ variable increases, which means that the maximum allowed mean square error percentage of 0.005 of the epoch variable is maintained. The Epoch variable: It is a complete iteration of the BackPropagation algorithm, this includes the data input, the forward propagation through all the layers of the neural network, the calculation of the error and the adjustment of the neuron weights for all the data of the training set.

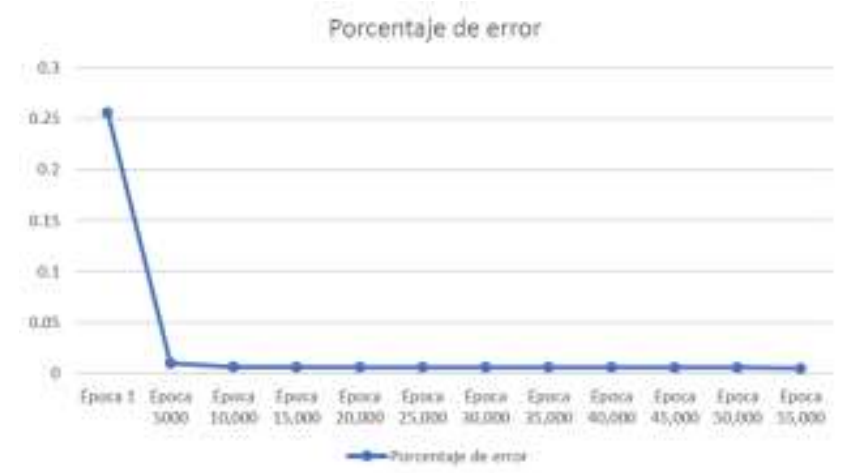

Figure 4 Percent error of the iris data set Source: Own Elaboration

\section{Implementation of the Neural Network with the crop data set.}

Data set

The dataset is composed of 8 data, which are:

1. Crop name

2. Crop family

3. Minimum humidity

4. Maximum humidity

5. Minimum temperature

6. Maximum temperature

7. Minimum $\mathrm{PH}$

8. Maximum PH

\section{Training}

The values that were used for training the neural network are:

\section{- $\quad$ An input layer of 5 neurons. \\ - $\quad$ Two hidden layers of 19 and 20 neurons respectively. \\ - $\quad$ An output layer with 51 neurons \\ - $\quad$ Learning factor 0.001 \\ - Maximum allowed root mean square error 0.005}

Figure 5 shows the result of the error percentage of the crop data set once the neural network is trained, the data of the graph shows that the variable $y$ does not vary when increasing the variable $\mathrm{x}$, which means that the maximum allowed mean square error percentage of 0.005 of the epoch variable is maintained. As already mentioned that the Epoch variable is a complete iteration of the BackPropagation algorithm, this includes data input, forward propagation through all the layers of the neural network, error calculation and adjustment of neuron weights for all the data in the training set.

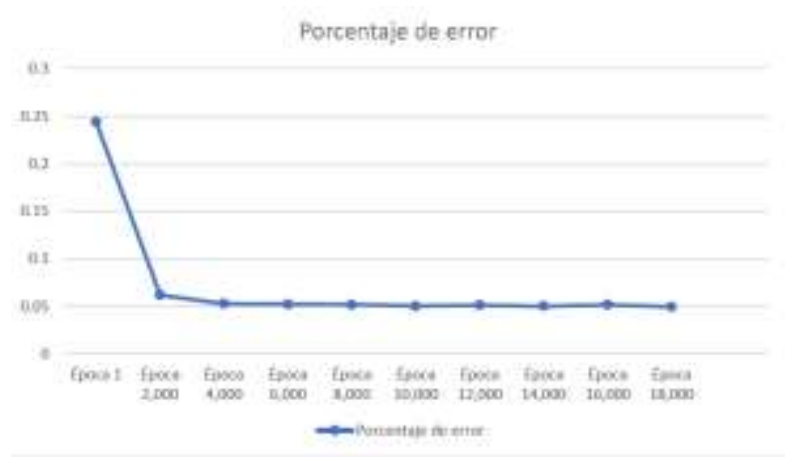

Figure 5 Percentage error of crop set Source: Own Elaboration 


\section{B. Presentation Phase:}

In this phase the neural network is already trained and can be used to solve a given problem. This phase describes the operation of the Data Analysis and Measurement modules that were designed and coded using the Java programming language and that were added to the expert system version 2.0 for its operation, using the prototype model. It is important to emphasize that for the purposes of this work only the two modules will be described, as the functionality of the entire expert system version 2.0 will be the subject of future work.

\section{Crop rotation}

The practice of planting different crops sequentially on the same piece of land to improve soil health, optimize nutrients, avoid pests, diseases and weeds. Figure 6 shows the 4-group 8-family crop rotation model that was used for the neural network tests.

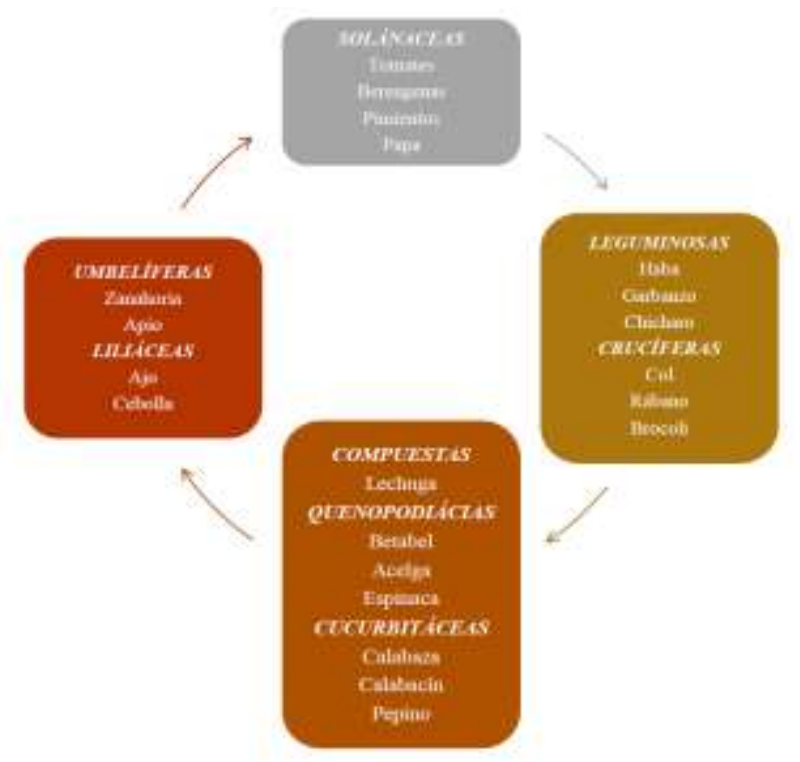

Figure 6 Crop rotation, 4 groups 8 crop families and rotations

Source:

(Pellicer,

2015)

https://blog.mundoikos.com/familias-de-cultivos-y-

rotaciones/

\section{Crop rotation description}

The rotation cycle starts with the first crop of Solanaceae, a demanding family as it requires a large amount of nutrients, especially nitrogen $(\mathrm{N})$. For this, if the soil is not rich in organic matter, it is advisable to add it, fertilizing it before sowing; once we have finished with the solanaceae, it is suggested to plant leguminous or cruciferous plants.
Both families are considered as improvers, mainly due to their characteristics in relation to the soil. Leguminous plants maintain a symbiosis in the soil with microorganisms of the Rhizobium genus, which fix atmospheric nitrogen and incorporate it into the soil, while crucifers are plants that improve soil structure due to their tap roots and also reincorporate sulfur (S) into the soil.

The next to be sown are the crops of medium demand, such as composites, quenopodiaceae or cucurbits.

Finally, there are the umbellifers and liliaceae, both of which are not very demanding at the nutritional level and leave the soil ready to be fertilized again and start the rotation cycle. (Pellicer, 2015).

\section{Development Methodology}

For the operation of the two modules the Prototyping model was used, this model aims at the direct participation of the customer in the construction of the required software, helps to improve the understanding of what is to be developed when the requirements are not clear and serves as a mechanism to identify and define the requirements of the software, also the prototype evolves through an iterative process, (Pressman, 2010, p. 37).

Figure 7 shows the stages: communication, rapid plan, rapid modeling and design, prototype construction, deployment, delivery and feedback.

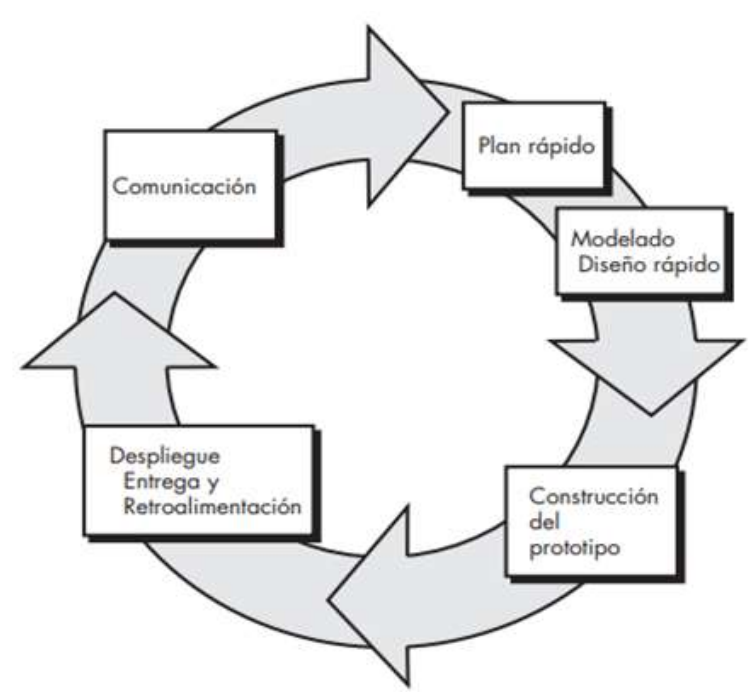

Figure 7 Model stages in prototypes Source. (Pressman, 2010, p. 37) 


\section{Development of the stages}

\section{First iteration:}

A. Communication stage, in this first stage interviews were conducted with the farmer to find out what were the real needs and problems presented, for example: identify manual processes, irrigation system, manual preparation of manure, fertilization, planting periods, harvesting, cutting, weather conditions in terms of humidity and temperature, type of crops planted, number of harvests, information that served to define the requirements, the definition of both general and specific objectives of the software, as well as users to interact with the system.

For the functionality of the modules, 3 types of users were identified with different roles and privileges to access the system:

- The Administrator user, who has full access to each of the modules, is in charge of adding data to the user system, new crops and new irrigation, soil analysis, measurements.

- The user Farmer, adds the data of sowings, harvests, process log, crops, history of sowings, harvests, crop rotation, soil analysis and measurements.

The guest user can only view information about crops, plantings, harvests, crop rotation, soil analysis and measurements.

B. The Quick Plan stage is carried out when the project results of the previous stage are accepted, then an abbreviated representation of the requirements is developed. For this project, the Use Case technique was used to model the requirements of the data acquisition module, an example of a Use Case for obtaining sensor data is shown in Figure 8.

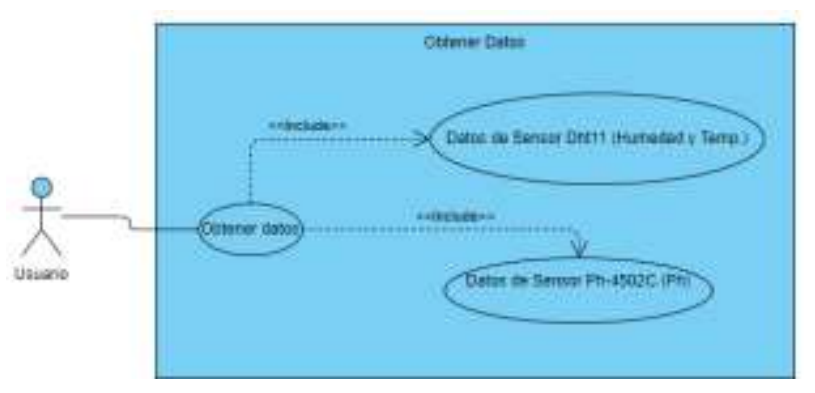

Figure 8 Sensor data collection use case Source: Source: Own Elaboration

C. In the rapid design modeling stage, different models were designed that serve as the basis for the correct operation of the system, such as sequence diagrams, the entityrelationship model, the circuit diagram design and the graphical user interfaces. As an example, a sequence diagram to execute the data acquisition program is shown. See figure 9.

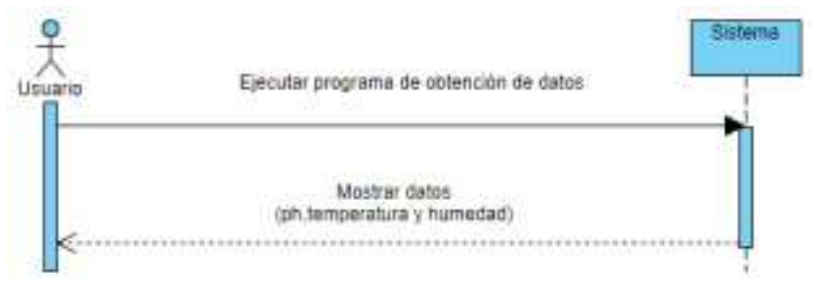

Figure 9 Sensor data collection use case Source: Own Elaboration

D. In the rapid design modeling stage, different models were designed that serve as the basis for the correct operation of the system, such as sequence diagrams, the entityrelationship model, the circuit diagram design and the graphical user interfaces.

As an example, a sequence diagram to execute the data acquisition program is shown. See figure 9.

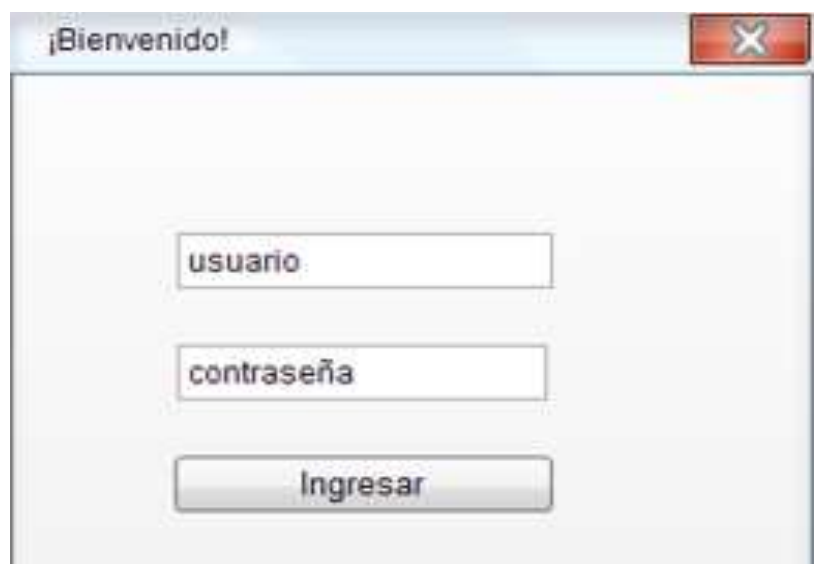

Figure 10 Access to the system Source: Own Elaboration

RAFAEL-PÉREZ, Eva, MONTERO-CORTÉS, Yeimi Yanet, RUIZ RAMÍREZ, Alan Eduardo and MORALES-HERNÁNDEZ, Maricela. Neural network for crop rotation and soil analysis in a Greenhouse. ECORFAN Journal-Democratic Republic of Congo. 2021 
E. In this stage of construction of a prototype, the circuit was built, only shown in Figure 11, since the description of the functionality will be a topic to be discussed in the future as mentioned above.

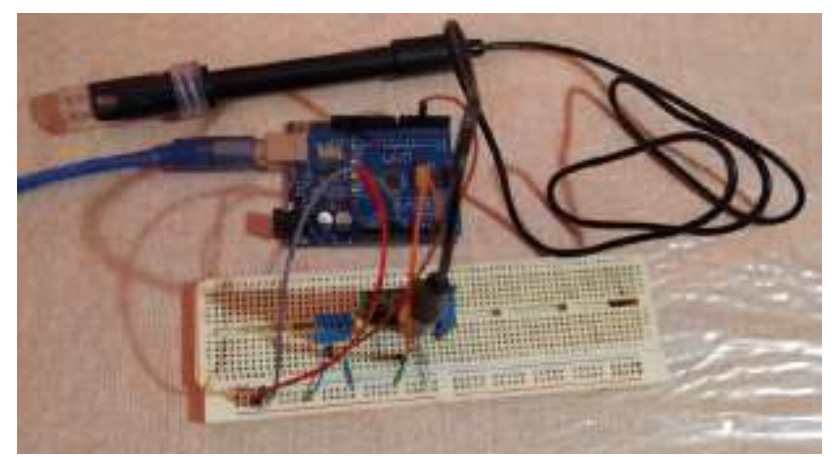

Figure 11 Circuits

Source: Own Elaboration

F. The last stage of deployment, delivery and feedback, the data acquisition module was tested with the variables of temperature, humidity of the environment and $\mathrm{pH}$ of the soil.

Prueba DHT11

Humedad: $18.00 \%$ Temperatura: $25.00^{\circ} \mathrm{C}$

Figure 12 Results of humidity and temperature of the environment Source: Own Elaboration

\section{Second Iteration module: Soil analysis}

A. Communication stage, in which the requirements of the soil analysis module were analyzed, the integration of the neural network in the expert system, as well as the specification of the process to obtain the data taking into account the crop rotation technique.

B. In the Quick Plan stage, a representation of the requirements was made by means of use cases to model the requirements of the soil analysis module.

C. In the Rapid Design Modeling stage, sequence diagrams were designed, two databases were created, both local and remote databases using the MySQL database management system. The remote database serves as a backup for the local database, if there is any problem with it, it can be recovered through the backup, also the remote database is updated every time there is an internet connection adding the newest data. The graphical user interfaces were also designed.
D. Prototype construction stage, in this stage the Soil Analysis and Measurements modules were developed, and Java programming language was used for their coding. In relation to the operation of the Soil Analysis module, it is linked to the Data Acquisition module by means of the Take Measurements button to obtain temperature, humidity and $\mathrm{pH}$ measurements.

The last stage of Deployment, delivery and feedback of the system, the design, phases, training and functionality of the neural network was tested.

\section{Results}

The results of the modules: Data Acquisition, Soil Analysis, Measurements and the implementation of the Neural Network are described below.

- Access to the system, to enter the system a user name and password are required. See Figure 13.

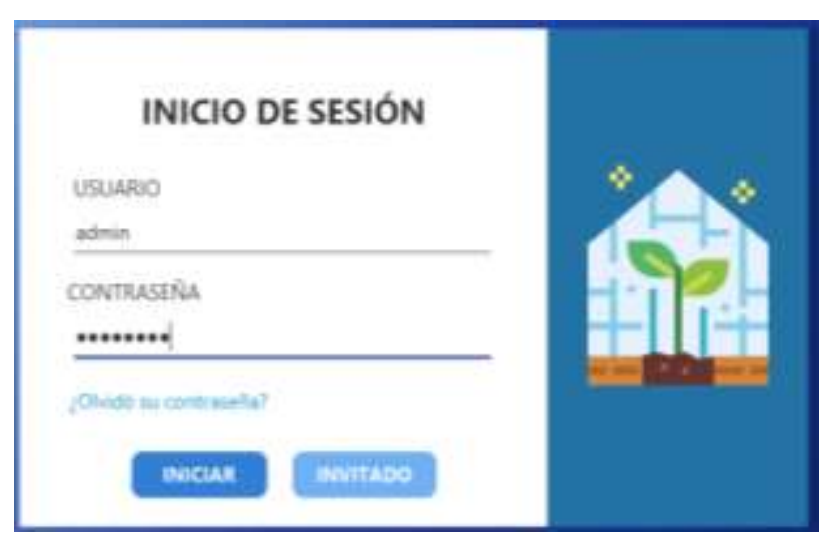

Figure 13 System access screen Source: Own Elaboration

\section{a) Results of the data acquisition module}

To perform the tests correctly, the following steps need to be followed:

1. Make a solution with two portions of water and one portion of soil in a container.

2. Shake said solution and let it stand for at least 15 minutes.

3. Clean the electrode nozzle with a dry and soft cloth to remove any existing solution as it may contaminate the sample made. 
4. After the 15 minutes of waiting, insert the electrode nozzle into the solution.

5. Run the data acquisition program.

Once the system is accessed, select the Soil Analysis module option, see Figure 14.

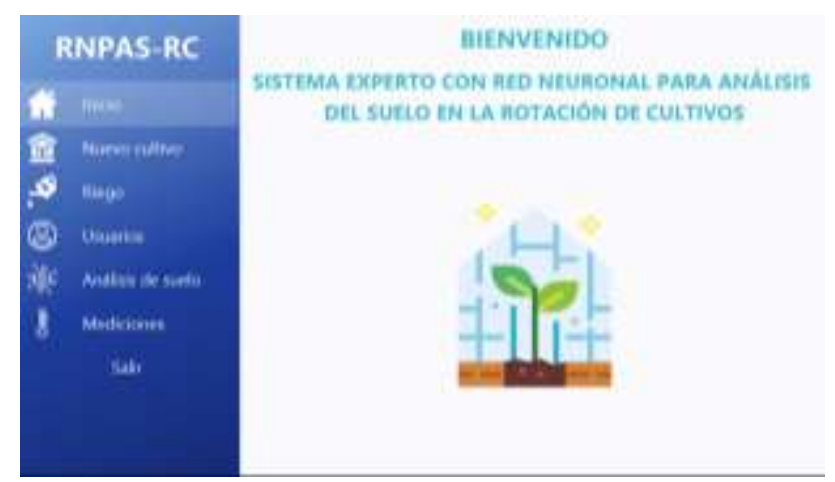

Figure 14 Soil analysis module

Source: Own Elaboration

When selecting the option, the system first validates that there is a connection with the data acquisition device, once validated, click on the Take measurements button to obtain the data, which internally takes 10 global measurements of temperature, humidity and $\mathrm{pH}$ and displays an average of the data obtained. See figure 15 .

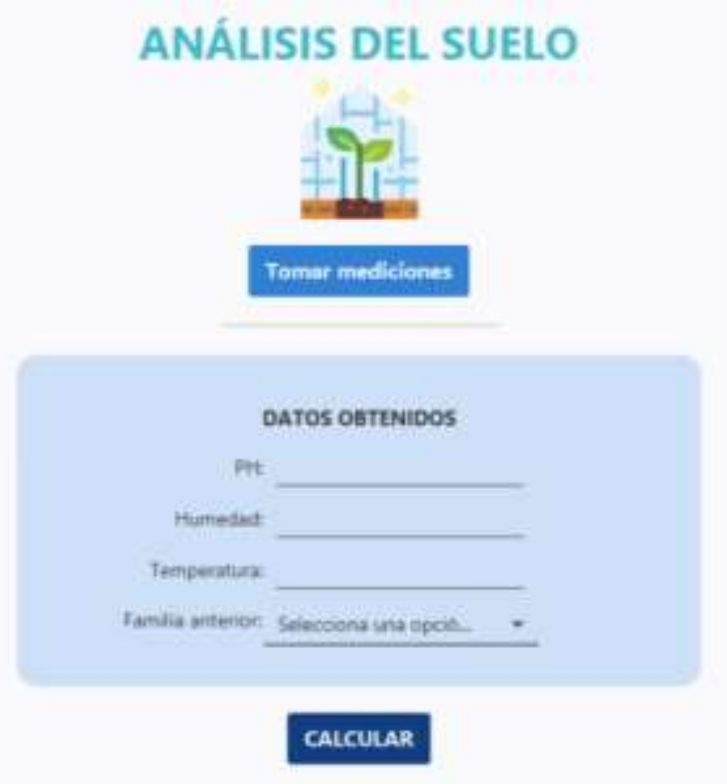

Figure 15 Take measurements button Source: Own Elaboration

When clicking on the Take measurements button, the following message is displayed to the user, see figure 16 .

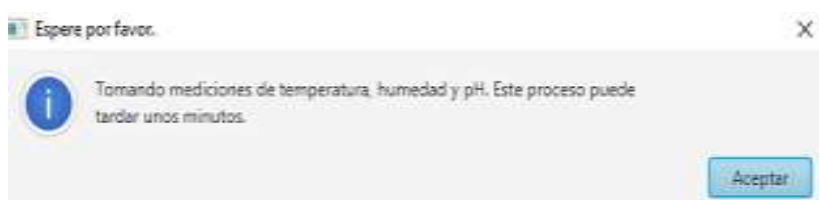

Figure 16 Temperature, humidity and $\mathrm{pH}$ measurement message

Source: Own Elaboration

Figure 17 shows the values obtained from the data acquisition module:

- $\quad$ PH: This text field shows the PH of the soil obtained by the data acquisition device.

- Humidity: This field shows the humidity of the environment obtained by the data acquisition device.

- Temperature: This field displays the temperature of the environment obtained by the data acquisition device.

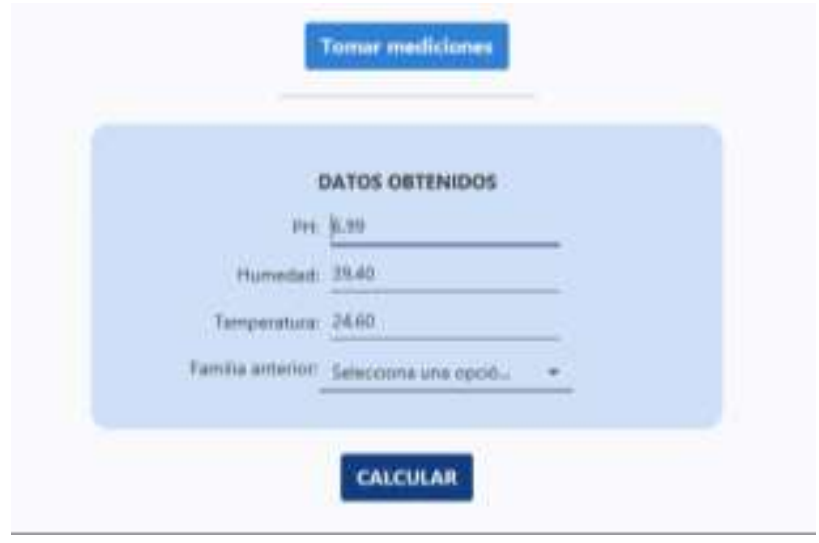

Figure 17 Values obtained

Source: Own Elaboration

\section{b) Results of the implementation of the Neural network}

When obtaining the data, it is necessary to select the previous family type that was previously seeded, when clicking on it, the 8 families are shown, for this example the Solanaceae family is chosen as shown in Figure 18. 


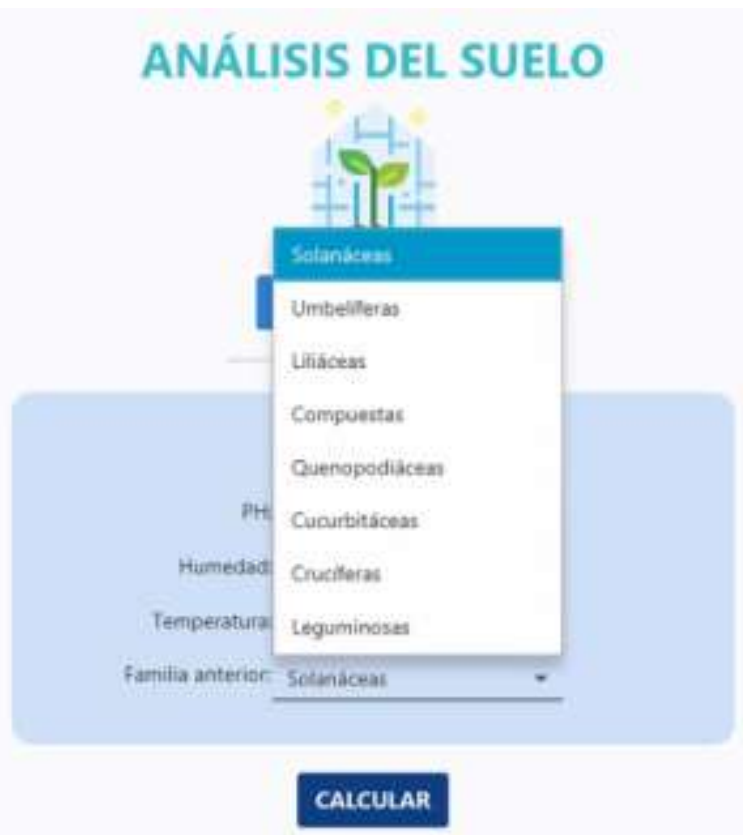

Figure 18 Selecting the family type above Source: Own Elaboration

Figure 19 shows the functionality of the neural network when clicking on the CALCULATE button, the neural network begins to perform the analysis and shows as a result the option of the most optimal type of crop to be planted.

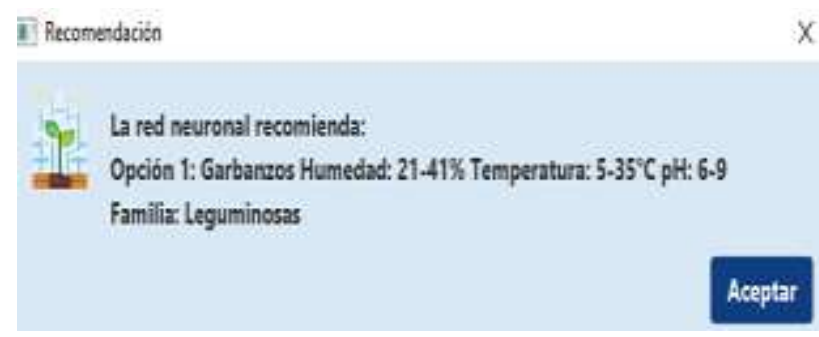

Figure 19 Result of the neural network functionality Source: Own Elaboration

\section{The results are:}

- $\quad$ The most optimal type of crop to plant is Chickpea.

- Optimum moisture values should be in the range of 20 to $41 \%$.

- $\quad$ The optimum temperature for the type of crop to be planted should be between 5 to $35^{\circ} \mathrm{C}$.

- $\quad$ The corresponding family is the legume family.

\section{c) Results of the Data Acquisition module using the Measurements module}

When clicking on the Measurements option, the system sends a message where the current measurements of temperature and humidity of the environment are being taken, see figure 20 .

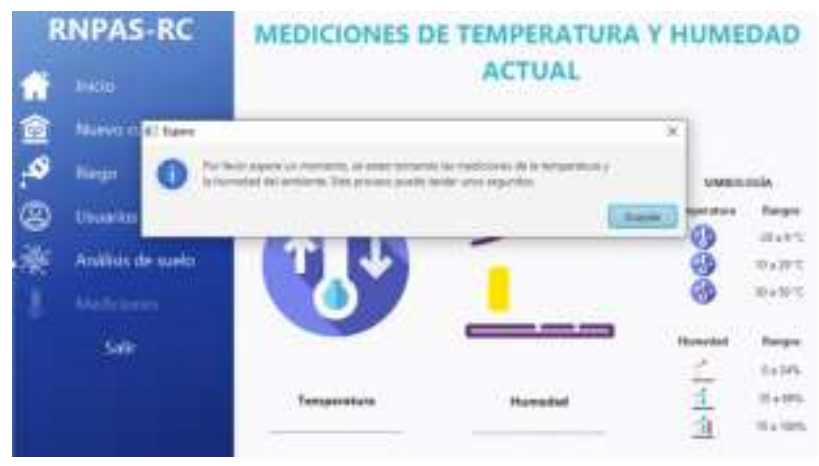

Figure 20 Measurement module Source: Own Elaboration

The measurements show in real time the temperature and humidity values, see figure 21 .

\section{MEDICIONES DE TEMPERATURA Y HUMEDAD ACTUAL}
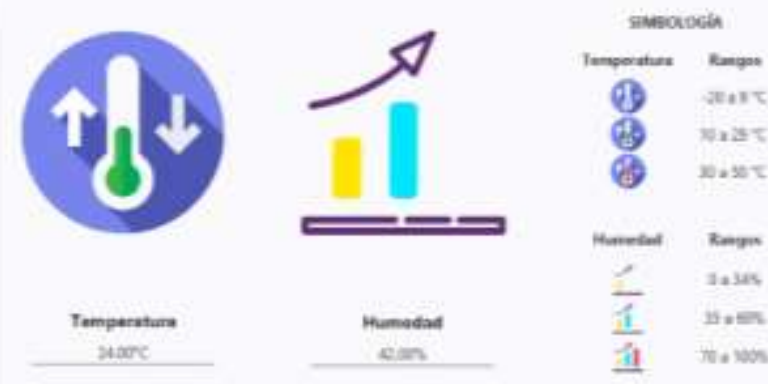

Figure 21 Measurements Module option Source: Own Elaboration

\section{Acknowledgments}

To the Tecnológico Nacional de México/Instituto Tecnológico de Oaxaca for the facilities and spaces for the development of this research work. We are grateful for the collaboration and dedication of the authors of the article, professors and students who participated with responsibility in the research until the achievement of the results presented; the objective of this research is to disseminate the findings to the academic community and the general public about the work being developed at the Institution. 


\section{Conclusions}

The neural network for crop rotation and soil analysis in a greenhouse was developed with the purpose of providing alternatives on the type of crop to be planted through crop rotation.

With the decision of the type of crop to be planted in the greenhouse, the risk of production loss can be reduced.

The solution to the problem posed is crop rotation, an alternative technique for the types of plants that are grown in the same place with the intention of not developing diseases that affect a specific family of crops and prevent the soil from being exhausted.

With the analysis of the optimal crop to be planted, the risk of loss of production would be considerably reduced, resulting in greater economic gains for the farmer.

The farmer is thus assured that his crop will obtain the best production according to the experience and knowledge of the neural network, in addition to optimizing the use of the soil and reducing the incidence of pests and diseases by interrupting their life cycles.

\section{References}

Ascencio Contreras, D. O. (2013). Evaluación del rendimiento de variedades de chile poblano en campo abierto y macrotunel. San Luis Potosí.

Barreto Barreto , A. (2006). Estudio de algunos componentes del comportamiento reproductivo del chile jalapeño. Coahuila .

Blanco M., C. (2017). Manual de producción de cebolla. Santiago: INIA.

Buschermohle, M., \& Grandle, G. (2020). Controlling the Environment in Greenhouses Used for Tomato Production. Obtenido de Agricultural Extension Service / The University of Tennessee: https://www.plantgrower.org/uploads/6/5/5/4/6 5545169/w017.pdf
Castellanos, J. 2007. Perspectivas de la agricultura protegida en México. In: Segunda Reunión Nacional de Innovación Agrícola y Forestal. Guadalajara, México. http://www.rniaf.org.mx/2007/memoria/ponenc ias/protegida/p4_perspectivas1.pdf

Carter, y Gregorich. (2007). Soil Sampling and Methods of Analysis. 2nd. Edition.

Centro Regional Patagonia Norte. (2006). Producción de hortalizas bajo cubierta. Argentina.

Collado, J. A. (s.f.). La Universidad Virtual.

Recuperado el 24 de Septiembre de 2014, de Concepto de Sistema de Información en la organización:

http://dpacomputacionunpa.files.wordpress.com /2011/10/1_conceptos_de_si_en_organ

izaciones.pdf.

Crawford L., H. (2017). Manual del manejo agronómico para el cultivo de melón. Santiago, Chile: Instituto de Investigaciones Agropecuarias (INIA).

Everardo, Z. (2016). El cultivo de la cebolla. Sonora: Universidad de Sonora.

FAO. (2013). El manejo del suelo en la producción de hortalizas con buenas prácticas agrícolas. Paraguay.

FAO. (2020). Producción Vegetal. http://www.fao.org/3/s8630s/s8630s08.htm

Fernández Fernández, M. M., Aguilar Pérez, M. I., Carrique Pérez, J. R., Tortosa Domingo, J., García García, C., López Rodríguez, M., y Pérez Morales, J. M. (2014). Suelo y medio ambiente en invernaderos. Sevilla: Consejería de Agricultura, Pesca y Desarrollo Rural

Gabino Alberto Martínez-Gutiérrez, René DíazPichardo, Griselda Juárez-Luis, Yolanda D. Ortiz-Hernández, Juana Y. López-Cruz. Caracterización de las unidades de producción de tomate en invernaderos de Oaxaca. Instituto Politécnico Nacional. CIIDIR Unidad Oaxaca, Hornos 1003, C.P. 71230, Santa Cruz Xoxocotlán. Oaxaca. México

Gary W. Hansen, J. V. (2014). Diseño y Administracion de Bases de Datos. Mexico: Prentice Hall.

RAFAEL-PÉREZ, Eva, MONTERO-CORTÉS, Yeimi Yanet, RUIZRAMÍREZ, Alan Eduardo and MORALES-HERNÁNDEZ, Maricela. Neural network for crop rotation and soil analysis in a Greenhouse. ECORFAN Journal-Democratic Republic of Congo. 2021 
Geographic, N. (2011). Crops. Obtenido de National Geographic Society: https://www.nationalgeographic.org/encycloped $\mathrm{ia} / \mathrm{crop} /$

Giandin, R. S., \& Pons, C. F. (2020). Relaciones entre Casos de Uso en el Unified Modeling Languaje. Revista colombiana de computación., 73-90.

Google Developers. (10 de Febrero de 2020). Redes neuronales de clases múltiples: Softmax. Obtenido de Redes neuronales de clases múltiples: Softmax:

https://developers.google.com/machine-

learning/crash-course/multi-class-neuralnetworks/softmax?hl=es

Horticultivos. (26 de Julio de 2017). Horticultivos. Obtenido de Principales tipos de invernaderos:

https://www.horticultivos.com/featured/princip ales-tipos-invernaderos/

Hydro Evironment. (10 de Febrero de 2020). Hydroenv. Obtenido de ¿Qué es un invernadero?:

https://www.hydroenv.com.mx/catalogo/index. php?main_page $=$ page \&id $=44$

Iberdrola. (2019). ¿Qué es la Inteligencia Artificial? Obtenido de ¿Somos conscientes de los retos y principales aplicaciones de la Inteligencia Artificial?: https://www.iberdrola.com/innovacion/que-esinteligencia-artificial

Ing. Agr. MSc. Miserendino, E., y Ing. Agr. Astorquizaga, R. (2014). Invernaderos: Aspectos básicos sobre estructura, construcción $\mathrm{y}$ condiciones ambientales. Buenos Aires: INTA.

Juárez L., P., Bugarín M., R., Castro B., R., Sánchez M., A., L., Cruz C., E., Juárez R., C., R., Alejo S., G., Balois M., R. Estructuras utilizadas en la agricultura protegida.

Juganaru Mathieu, M. (2014). Introducción a la programación. México: Patria.

Martínez Ladrón de Guevara, J. (2014). Fundamentos de programación en Java. Madrid: EME.
Moreno Reséndez, Alejandro; Aguilar Durón, Juanita; Luévano González, Armando. Características de la agricultura protegida y su entorno en México

Mujica, A., Canahua, A., \& Saravia, R. (2020). FAO . Agronomia del cultivo de la quinua: http://www.fao.org/tempref/GI/Reserved/FTP_ FaoRlc/old/prior/segalim/prodalim/prodveg/cdr om/contenido/libro03/cap2.htm\#: :text=La\%20 siembra\%20se\%20debe\%20realizar,la\%20germ inaci\%C3\%B3n\%20de\%20las\%20semillas.

MySQL. (2020). MySQL Documentation. https://dev.mysql.com/doc/

Nevado, M. (2010). Introducción a Las Bases de Datos Relacionales. España: Visión Libros

Pellicer, P. (12 de Marzo de 2015). mundoikos. Obtenido de Familias de cultivos y rotaciones: https://blog.mundoikos.com/familias-decultivos-y-rotaciones/

Pressman S., R. (2010). Ingeniería de Software. New York: Mc Graw Hill.

Ramón López , J. (18 de Octubre de 2017). Catalunyaplants. Obtenido de La importancia de la luz en las plantas: https://www.catalunyaplants.com/laimportancia-de-la-luz-en-las-plantas/

Ramos, M. J., Ramos, A., \& Montero, F. (2006). Gestores de bases de datos. Madrid: Mc Graw Hill.

Rangel Campos, L. (2016). Crecimiento del chile habanero. Coahuila.

Reveles Hernández, M., Huchín Alarcón, S., Velásquez Valle, R., Trejo Calzada, R., \& Ruiz Torres, J. (2010). Producción de plántula de chile en invernadero. Durango: SAGARPA.

Revista Mexicana de Agronegocios, núm. 29, julio-diciembre, 2011, pp. 763-774. Sociedad Mexicana de Administración Agropecuaria A.C. Torreón, México

Rodale Institute. (12 de Enero de 2019). Rodale Institute. Obtenido de Crop Rotations: https://rodaleinstitute.org/why-organic/organicfarming-practices/crop-rotations/

Rojas Bertini, C. (2011). Cultivo de alcachofa. Arica, Chile: INIA.

RAFAEL-PÉREZ, Eva, MONTERO-CORTÉS, Yeimi Yanet, RUIZRAMÍREZ, Alan Eduardo and MORALES-HERNÁNDEZ, Maricela. Neural network for crop rotation and soil analysis in a Greenhouse. ECORFAN Journal-Democratic Republic of Congo. 2021 
Rusell, S. J., \& Norving, P. (2004). Inteligencia Artificial. Pearson Eduación. Obtenido de https://www.ibm.com/support/knowledgecenter /es/SS3RA7_sub/modeler_mai

nhelp_client_ddita/components/neuralnet/neura lnet_model.html

Salcedo, J. M. (2020). Guías para la regeneración de germoplasma- Frijol común. Cali, Colombia: Oficina Regional para las Américas.

Secretaría de Desarrollo Agropecuario. (2020). Requerimientos agroecológicos de cultivos. Obtenido de http://sedea.queretaro.gob.mx/sites/sedea.queret aro.gob.mx/files/BETABEL.pdf

Snyder, R. G. (2016). Guía del cultivo del tomate en invernaderos . Extension of Mississippi State University.

Steven Perry, J. (3 de 12 de 2012). Conceptos básicos del lenguaje Java. Obtenido de Programación orientada a objetos en la plataforma Java: https://www.ibm.com/developerworks/ssa/java/ tutorials/j-introtojava1/index.html

Unidad Académica de Agricultura, Universidad Autónoma de Nayarit, Departamento de Fitotecnia, Universidad Autónoma Chapingo

Universidad de Barcelona. (2020). OBS. Obtenido de ¿Qué son las metodologías de desarrollo de software?: https://obsbusiness.school/es/blog-projectmanagement/metodologia-agile/que-son-lasmetodologias-de-desarrollo-de-software

University of Massachusetts Amherst. (17 de Enero de 2013). Garlic Harvest, Curing and Storage. Obtenido de https://ag.umass.edu/vegetable/factsheets/garlic-harvest-curing-storage

Valencia Reyes, M. A., Yañez Márquez, C., \& Sánchez Chávez, L. P. (2006). Algoritmo Backpropagation para Redes Neuronales: conceptos y aplicaciones. Instituto Tecnológico Nacional.

Villalobos Reyes, S., Guzmán Maldonado, S. H., Escobedo López , D., \& Gonzaléz Pérez, E. (2018). Componentes agronómicos y diversidad en el patrón de ácidos grasos. Revista Mexicana de Ciencias Agrícolas.
Zárate Aquino, M. (2014). Manual de Hidroponia. Distrito Federal: Universidad Nacional Autónoma de México.
RAFAEL-PÉREZ, Eva, MONTERO-CORTÉS, Yeimi Yanet, RUIZRAMÍREZ, Alan Eduardo and MORALES-HERNÁNDEZ, Maricela. Neural network for crop rotation and soil analysis in a Greenhouse. ECORFAN Journal-Democratic Republic of Congo. 2021 